\title{
Religiosity and Psychological Well-Being on The Generation $Z$ of Divorced Parents at Urban Society
}

\author{
Ihya Addini Islami ${ }^{1}$, Nurwahidin ${ }^{2}$, Thobib Al-Asyhar ${ }^{3}$, Renny Nurhasana ${ }^{4}$ \\ \{1'Ihya92ui@gmail.com, ${ }^{2}$ nurwahidin@ui.ac.id, ${ }^{3}$ thobieb_smg@yahoo.com, ${ }^{4}$ rennynurhasana@ui.ac.id $\}$ \\ ${ }^{1,2,3,4}$ School of Strategic and Global Studies, Universitas Indonesia, Indonesia
}

\begin{abstract}
Generation $\mathrm{Z}$ tends to be susceptible to conflicts and mood swings related with parental divorce. Psychological well-being can be a factor that helps them to perform their psychological function well, to know their potential, and to have meaningful life. In addition, religiosity can also help reduce anxiety, stress and fortify from various psychological and behavioral disorders. This study aims to obtain a description of religiosity and psychological well-being on generation $\mathrm{Z}$ of divorced parents at urban society. Different from some previous research which many use quantitative approaches, this research use qualitative descriptive method with phenomenological approaches and use data from deep interview and observation with 5 participants. The assumption of this research is most participants have high psychological well-being and religiosity in several different dimensions.
\end{abstract}

Keywords: Divorced Parents; Generation Z; Psychological Well Being; Religiosity

\section{INTRODUCTION}

Parental divorce is certainly not something that children like. Divorce which is generally covered by disputes and even quarrels not only has a psychological impact on the husband and wife but also on the child, especially on teenagers. Families who are expected to play a role in every development of adolescents in it and give a great influence in the formation and development of the child's personality become lost due to divorce. Adolescents in which the development stage requires a family environment that supports themselves to be able to develop optimally in a positive direction.

The phenomenon of divorce, especially in Indonesia, has increased from year to year. Based on data from the Ministry of Religion, the divorce rate for the 2014-2016 period from 344,237 rose to 365,633 divorces in 2016. The average divorce rate rose 3 percent per year. Indonesia's divorce rate is highest in Asia Pacific. From 2009-2015 every one hour there are 40 divorce hearings or 340,000 more divorce claims. In addition, referring to the divorce data for the 20152017 period, the highest number of divorce cities is occupied by Surabaya, Bandung and Semarang. This is a picture of the number of urban children who have lost the integrity of their families.

Divorce is a major transition and heavy adjustment for children, parents, and other family members (Chen and George, 2005). Especially for a teenager, family transitions lead to an 
emotional reaction and behavioral change, not even a few children who experience prolonged suffering and misery because their parents divorced. As quoted by Fadila (in Akuindonesiana, 2013), the adverse effects of divorce on children mention some of the consequences of which are the tendency to drink alcoholic beverages, use illegal drugs, and even want to commit suicide. Many children also express their unhappiness, feel unloved by parents, and left to grieve.

A large number of family research has shown that children from divorce tend to experience difficulties in psychological, social, and academic terms than children who are raised in whole families (Amato, 1993; Demo \& Acock, 1988 in Sun, 2001). Similar results were also found by Sarbini in her research on the psychological condition of children from families divorced with the subject of children from divorced families aged 6-17 years. The results of this study indicate that the psychology of children from divorced families has a negative impact, such as low selfesteem on the environment, temperament, and prolonged feelings of disappointment towards parents. This certainly has a long impact on its future.

But on the other hand, teenagers who are victims of parental divorce do not always end badly. Teenagers with the condition of parents separating are also challenged to succeed and be successful and live their lives well and full of optimism. This is supported by Nelsen (1999) which states that not all parental divorce ends badly for children. Many of the child victims of divorce have outstanding achievements in various fields, both academic and non-academic. Child's perception of his parents' divorce affects his future optimism.

In a psychological perspective, special abilities that can help individuals to overcome life's difficulties are religiosity. The results of research conducted by Argyle (in Amawidyati, 2007), states that religiosity helps individuals maintain individual mental health at difficult times. Religiosity is considered as a foundation in facing all situations, whether pleasant or miserable, and still able to be optimistic with confidence in the help and help of his Lord. Ellison's research shows that individuals who have strong religious beliefs reported higher life satisfaction, higher personal happiness, and experienced a lower negative impact of traumatic events than individuals who did not have strong religious beliefs. This belief will strengthen itself in preventing various possible psychological disorders and deviant behavior. Disclosed by Batasman (in Saputri, 2013) also states that individuals who have a high level of religiosity are better able to interpret each occurrence of life positively, so that their lives become more meaningful and avoid stress or depression.

Besides religiosity factors, psychological well-being is considered capable of being one of the factors needed by teenagers from divorced parents to help them rise again and be able to adapt positively. The presence of psychological well-being in the child makes him able to perform his psychological function well, allowing him to know his potential, including learning and achieving, and experiencing a more meaningful life. PWB focuses on self-realization, personal expression, and the extent to which an individual is able to actualize his potential (Waterman, in Ryan \& Deci, 2001).

Regarding research subjects, researchers are interested in researching adolescents from generation $\mathrm{Z}$. In addition to the relatively rare research on this geeration, generation $\mathrm{Z}$ also has distinctive characteristics compared to adolescents living in other generations. Generation $\mathrm{Z}$ is those born in the era of digital technology with the period of 1995-2012, with characteristics such as being fluent in technology, instantaneous, tend to have a high tolerance for cultural and environmental differences, and multitasking. From the above explanation, religiosity and psychological well-being of generation $\mathrm{Z}$ teenagers from divorced parents should be disrupted due to their parents' divorce. Based on these assumptions, in this study researchers wanted to provide an overview of religiosity and psychological well-being of generation $\mathrm{Z}$ from divorced 
parents, including what factors influenced it. It is on this background that makes researchers interested in examining how the picture of religiosity and psychological well-being generation $\mathrm{z}$ from parents divorced. The question that arises in this research is: how is the picture of generation $\mathrm{Z}$ religiosity from parents divorced? How does the $\mathrm{z}$ generation of psychological well-being from parents divorce? What factors influence both? This research is expected to provide an overview of generation $\mathrm{Z}$ religiosity from divorced parents. In addition, this research is expected as an effort to integrate Islamic values in understanding family psychology.

Based on the above background it can be concluded that the motivation underlying the need for this research is to find out the description of $\mathrm{Z}$ generation religiosity from divorced parents and to know the picture of the $\mathrm{Z}$ generation of psychological well-being from divorced parents.

\section{LITERATURE REVIEW}

\subsection{Religiosity}

Religiosity is interpreted by the general public as a religious ritual practice. One's religiosity can be seen from the personality that is raised by describing the integral building of the religious human self, including his insights, his motivation, his way of thinking, his behavior and his attitude. Rachmat (2004) defines religiosity as a condition that exists in an individual that encourages him to behave according to the level of obedience to religion. While Glock and Stark (in Nashori, 2007) define religiosity as a system of symbols, belief systems, value systems, and institutionalized systems of behavior, all of which focus on issues that are perceived as the most meaningful. So it can be concluded that religiosity is an integrated system related to knowledge, belief, implementation of worship, and human appreciation of God.

Related to the aspect of religiosity, Gloc Stark mentions five subjects, namely: 1) The ideological dimension relates to the level of a person in believing in the truth of his religious belief. 2) The ritualistic aspect (the ritualistic dimension) is the level of compliance of a person who teaches ritual obligations, as instructed by his religion (religious practice). 3) The experiential dimension is the level of a person in feeling and experiencing religious feelings or experiences. 4) The intellectual aspect (the intellectual dimension) is related to the level of one's knowledge and understanding of religious teachings (religious knowledge). 5) Consequential dimension, which is the aspect that regulates the extent to which a person's behavior is motivated by the teachings of his religion in social life, namely how individuals relate to the world, especially with fellow human beings (religious effect).

\subsection{Psychological Well-Being}

Psychological well-being, also known as eudaimonic well-being (Ryff, 1989), deals with the concept of actualizing human potential in facing life's challenges. The psychological wellbeing approach focuses on self-realization, personal expression, and the extent to which an individual is able to actualize his potential (Waterman, in Ryan \& Deci, 2001). Ryff \& Singer said that psychological well-being is not just an effort to gain happiness, but also the struggle to be the best by realizing the true potential (true potential) (Ryff 1995, in Ryan \& Deci, 2001). Constructions in the psychological well-being dimension both theoretically and operationally are closely related to matters relating to mental and physical health. This is similar to what Ryff and Keyes said that psychological well-being can affect physiological systems related to immunological functions and things that support health (Ryff \& Singer 1998, in Ryan \& Deci, 2001). 
Thus it can be concluded that psychological well-being is an individual's condition in order to fulfill self potential which is characterized by independent in acting and free from social pressure (autonomy), able to recognize the improvement of self quality over time (personal growth), accepting shortcomings and advantages self (self-acceptance), has a purpose in life and knows the steps to achieve it (purpose in live), able to create and choose an environment that suits your personal values and needs (environmental mastery) and is able to establish harmonious relationships with others (positive relationships with others ) Meanwhile the factors that influence psychological well-being are 1) demographic factors including age, gender, socioeconomic status, and culture, 2) social support factors, 3) giving meaning to life, 4) personality.

\subsection{Divorce}

Divorce is divorced between married couples as a result of their failure to carry out their respective roles, in this case divorce is seen as the end of a marital instability where the husband and wife then live separately and are officially recognized by applicable law. In addition, according to Yusuf (2004) parental divorce is a family condition that is not harmonious, unstable or messy. From the two meanings above, it can be concluded that divorce is the end of a husband and wife relationship due to incompatibility between the two and is decided by law.

\subsection{Generation $Z$}

Generation $\mathrm{Z}$ or Internet Generation are those who live in digital times or when the internet starts to enter and thrive in human life. Hellen Chou P. (2012: 35) gives the understanding that the term $\mathrm{Z}$ generation is a young generation that grows and develops with a great dependence on digital technology, so it is not surprising that at a young age, people who are still students are skilled in mastering technology. Schroer (2015) stated in his research that the period of birth for Generation Z was from 1995 to 2012. This was supported by Elizabeth T. Santosa in his book entitled Raising Children in Digital Era which states that Generation $\mathrm{Z}$ is a generation born in that year. This certainly affects the development of behavior, personality, even in education and learning outcomes. While related to behavioral and personality characteristics that are different when compared to the previous generation, according to Akhmad Sudrajat, Generation $\mathrm{Z}$ has the following characteristics: 1) fluent in technology, generation $\mathrm{Z}$ is a person who is adept and familiar with the use of information technology and can be easily and quickly accessed for the sake of daily life as well as educational interests. Research by Jaleniauskiene \& Juceviciene shows that due to intensive exposure to the internet; they prefer watching videos rather than reading hardcopy media; books and manuals. 2) social, generation $\mathrm{Z}$ is those who have a longer time to communicate and interact with many people in various circles, both with peers, younger people, even older ones through various social networking sites. 3) Multitasking, generation $\mathrm{Z}$ is used to doing various activities at the same time, such as reading, talking, watching, or listening to music at the same time. Elizabeth T. Santosa (2015: 20) mentions several indicators of adolescents belonging to Generation $\mathrm{Z}$ : 1) having big ambitions for success, they tend to have positive and optimistic characters in reaching their dreams, 2) tend to be practical and behave instantaneously. 


\section{PRESENTATION OF DATA AND FINDINGS}

\subsection{Phenomonological}

This study uses qualitative research. This study uses a psychological and spiritual perspective of Islam with a phenomenological approach. The reason for choosing this approach is to get a picture of the meaning of the life experiences experienced and describe a number of phenomena, backgrounds, and potentials of generation $\mathrm{Z}$ from divorced parents. Data collection techniques in this study are based on sources selected purposively. Subjects taken in this study amounted to 5 generation $\mathrm{Z}$ people from divorced parents. Research subjects were taken based on the following criteria:

1. 17-23 years old

2. Islam

3. Living in Jakarta

4. There are no gender restrictions

5. Parental divorce happened at least 5 years ago

Selection of subjects using convenience sampling technique, namely choosing subjects that are easily accessible to researchers (Howitt \& Cramer, 2011).

Data extraction techniques used in this study are literature studies and field studies. Literature studies come from books, journals and the internet, as well as the opinions of experts. While the field study was conducted through interviews, interview techniques were conducted in an open and semi-structured manner. Most of the interviews conducted in this study were by using a recorder with the permission of the informant.

The instrument used is a list of research questions compiled by researchers based on research indicators related to Glock and Star's religiosity and psychological well-being within the framework of Ryff's theory. Data analysis techniques through 3 coding processes (Strauss and Corbin, 1990), namely: 1) open coding, 2) axial coding, 3) selective coding. During the first phase of this coding process, data is compared, and different categories are identified. Then in axial coding, the data is combined which makes possible the relationship between categories. While selective coding, organize and integrate categories.

\subsection{Analysis presented}

The general profile of the six subjects is as follows:

Table 1. profile of the six subjects

\begin{tabular}{|c|c|c|c|c|c|c|}
\hline Name & Gender & Age & Activity & $\begin{array}{c}\text { That Cause } \\
\text { Divorce }\end{array}$ & $\begin{array}{c}\text { Parents' } \\
\text { Divorce Since }\end{array}$ & Live With \\
\hline IP & M & 22 & Working & $\begin{array}{c}\text { Inability to } \\
\text { Earn }\end{array}$ & 6 Years Old & Grandmother \\
\hline MAL & F & 17 & Sma & Infidelity & 15 Years Old & Father \\
\hline SUF & M & 17 & Sma & Infidelity & 3 Years Old & Mother \\
\hline NAQ & F & 22 & $\begin{array}{c}\text { Student } \\
\text { University }\end{array}$ & $\begin{array}{c}\text { Inability to } \\
\text { Earn }\end{array}$ & 14 Years Old & Mother \\
\hline DEL & F & 17 & Sma & Drug Use & 3 Years Old & Mother \\
\hline
\end{tabular}




\subsection{Religiosity Analysis}

Religiosity is seen from several dimensions including, dimension of belief or ideology, dimension of practice of religion or worship, dimension experience, dimension of religious knowledge, and consequent dimension. In the dimension of belief, indicators believe in the existence of God, various subject explanations. But researchers can take the essence that there is a similarity in their understanding of the indicator that is due to the fulfillment of desire or prayer. Fulfillment of prayers includes help when overcoming difficulties. There are favors of life and concrete proof of God's punishment for those who desecrate God and religious symbols also become answers. The five subjects said that they believed and surrendered to God's destiny for divorce that occurred in parents. The subjects of LIK, QYA, and SUF said that they always mentioned the name of God before and after carrying out their activities. After observing the three, the researchers did witness many times mentioning and praising the name of God, both when they saw beauty, sneezing, coughing, almost falling, and so on. Unlike the others, IP and DEL claimed that they rarely prayed and mentioned God's name in their activities.

While in the ritualistic dimension, all subjects carry out compulsory worship, including 5 daily prayers, Ramadan fasting, and zakat. but 3 of them are SUF, IP, and DEL researchers found data that occasionally they neglected consciously and unconsciously, for example not dawn prayer because of waking up late. Regarding sunnah worship, the intensity of worship LIK, QYA, and SUF is greater than IP, and DEL. QYA and SUF admitted that since childhood they had been accustomed to parents doing a lot of worship, while LIK diligently worshiped since he decided to migrate. The sunnah worship is fasting on Monday Thursday, rawatib prayer, duha prayer, tahajud prayer, and so on. Regarding participation in religious activities, LIK and QYA were the most prominent. Both of them are active in taking part in routine study sessions, majlis ta'lim, and faith-based organizations. While 3 other subjects tended to attend studies or lectures through videos on youtube and social media. But no doubt LIK and QYA were actively increasing religious insight through social media. Related to the da'wah activities they do, their responses tend to have similarities, such as giving examples, giving verbal advice and through status or writing on social media.

In the experiential dimension, when asked about how to deal with God's trials in the form of parental divorce, subjects said that they chose patience and surrender, even though initially there was a feeling of extreme sadness, regret, and anger. Slightly different from the others, QYA said that since childhood, parents had been accustomed to reading motivational books on life, so that he could receive all the tests of his life because he was convinced that behind every accident, there was always goodness. In addition to being patient and submissive to God's will, the subject also found wisdom in the divorce of his parents. LIK for example, he feels his family relationship is more peaceful or no longer at odds after divorce than before. While QYA feels more religious. This is evidenced by his diligence in carrying out religious orders. He added that he had learned how to selectively choose a partner and how to apply good parenting. Regarding this aspect, the subjects feel that they are supervised by God, especially when they are negligent or want to commit immorality. For example DEL, he explained when he wanted to kiss and was invited to have sex with his girlfriend, he felt God shielding him. Likewise IP, he is sure every time after committing a sin, he will get a disaster or a direct reply from God.

Whereas in the intellectual dimension, not all subjects study religion. DEL for example, he claimed to attend a series of religious events only when invited by his peers. Unlike the others, QYA and LIK are actually excited and feel called to explore their religion, including by taking classes in memorizing the Quran, tahsin (the science of improving the recitation of the quran), following scientific forums, such as the science of interpretation and interpretation. In the 
indicator of noting halal haram, some subjects claimed to be inclined to ignore. For example, when charging a cellphone, QYA does it in mosques or places that have not given their use permits, while SUF claims to often use their dorm's sandals without permission. At different times, LIK claimed to be very strict in halal-haram matters. However, he realized that while traveling with a large family, he had difficulty eating food that had not received a halal label from the government. Finally, consequential aspects, the five subjects admitted that they had a good relationship with humans. This is also recognized by people closest to the subject, based on the observations of researchers. This happens because the five subjects have good character or attitude towards the surroundings.

\subsection{Psychological Well-Being Analysis}

Psychological Well Being is seen based on dimension autonomy, dimension of mastery of the environment, dimension of personal growth, dimension of positive relationships with others, and dimension of purpose of life. In the autonomy dimension, 4 out of 5 subjects claim to remain at the stand when ideas or ideas are opposed by others. But if his opinion is denied by a large number of people, only 3 subjects can survive. The rest chose to just give up. Regarding the dimension of environmental control, all subjects recognized by their environment have a significant influence. For example, the IP subject is the chairman of the futsal team in his environment, while the organization or an activity does not run or goes smoothly without his presence. While the other 3 subjects stated that each of them was a manager in a large organization, a leader in a number of activities, and a place to share the stories of his friends. This proves that the five subjects are able to control even the complex environment and participate in the opportunities that come.

With regard to indicators creating situations that are appropriate to personal needs and values, 4 subjects are people who do not like to follow trends or situations if they are contrary to personal values and instead tend to be an inspiration to the environment. Whereas 1 person called himself occasionally to follow. In the personal growth dimension, in the indicator feel the existence of continuous self-development, IP tends to be confused to answer it. In the observation phase, it was found that he was a teenager who tended to be relaxed and not so passionate about self-development. While the other 4 subjects felt self-development and selfpotential, for example SUF admitted that he felt more mature because of the divorce of his parents. He is also active in many activities. Besides that, he was recognized by the environment for choosing a lot of self potential, such as debates, public speaking, speeches, and making short stories and poetry. Interestingly, DEL who previously claimed to be a drug user and hobby, felt that his worship was getting better now. While LIK and QIY, both have similarities in developing themselves in several organizations with the aim of getting out of the comfort zone and fostering leadership skills. In the indicator having increased knowledge, all subjects tend to answer they get lessons related to marriage, such as how to be loyal to a partner, selective in choosing a partner, and how to be good towards a partner later.

In the dimensions of positive relationships with others, the five subjects were identified as being able to establish warm relationships and gain the trust of others. This happened because the communication was smooth and good, honest, have empathy that is strong, humorous, friendly, confidential, and loving. LIK added that in establishing relationships he tried not to be easily offended, while SUF claimed to often give a surprise to maintain good relations. Regarding indicators understanding the concept of receiving and giving in interpersonal relationships, all subjects do not expect a reply from the gift they give to others. the next, in the dimensions of the purpose of life, IP, LIK, and DEL said they wanted to make people happy 
who had raised and cared for them, namely parents and grandmothers. All three are sure to achieve the goals of life with effort and hard work. While QIY, the purpose of his life is to go to heaven and become the next of siti Khadijah and Abdurrahman bin auf or successful entrepreneurs. He is now starting with trading and attending a series of digitalpreneur seminars in his city. What is unique is SUF, he honestly said the purpose of his life was to marry early. The reason is that his partner will become his life's motivation to achieve his dreams. In the indicator of knowing the meaning of life in the past and present, they answer with the same answer, which is to make the past a life lesson and motivation in the future and to carry out the present as well as possible.

The last is the dimension of self-acceptance. In this dimension, the DEL subject claimed he was very stubborn if he received advice from his parents, tempered, sensitive, and fierce. Even so, he saw that there was goodness in him in the form of confidence that could be optimized. Although he claimed to have many flaws, he was determined to be self-introspective. While the subject of SUF views itself as money oriented, lazy, and likes to ask for help from others. even so, he considered himself to be a cheerful person and made others cheerful through his humor. Not much different from the others, both IP, LIK, and QYA also have positive thoughts about themselves and accept their strengths and weaknesses. This can be seen from their statement that they are currently actively honing their potential through asking many experts, following scientific studies, expanding networks, joining organizations that support potential, selflearning, whose purpose is to actualize and optimize themselves.

\section{ANALYSIS}

Each subject has the advantages and disadvantages of their respective aspects of religiosity. However, overall five teenagers have good religiosity. This is identified through aspects of religiosity and derived indicators. In the aspect of belief, believing in the existence of God with the fulfillment of prayer and hope is the understanding of most subjects. Argyle (2001), states that religiosity helps individuals maintain individual mental health in difficult times. Subjects include the name of God in every activity, both happy and difficult. The factor is their habit from the small that is exemplified by his parents. Others claimed not to be accustomed to parents. In matters related to ritualistic, in obligatory worship and sunnah most subjects carry it out quite well. The blessings that God has given and the notion that worship has become a necessity that drives it. Listening to religious studies through youtube and other social media dominates the way in which subjects gain religious insight.

Teenagers who are the subject of research are part of generation $\mathrm{Z}$ who have a high interaction with digital technology (Wiedner, 2015). This is a positive thing from the use of technology. In the condition of parents who are not intact the subject continues to call for kindness or da'wah in the form of exemplary, giving verbal advice and through status or writing on social media. The use of social media as a means of da'wah is a lifestyle that does not appear in previous generations. Choose patience and surrender, even though initially there is a feeling of extreme sadness, regret, and anger is the attitude chosen. According to Woofolk (2008, in Aminah, 2012) however divorce is not easy for adolescents, a process or step is needed to help adolescents reach the stage of self-acceptance of parents' decision to divorce. The habits that are implanted by parents read motivational books of life, so that they can receive all the tests of their lives because they believe that behind every accident there is goodness as well as being a factor in taking someone's patience. Become more religious as the choice taken. Najati (2005) religious or religious life can help humans reduce anxiety, anxiety and tension. Parental divorce 
is considered to be the provision of subjects in later married life, including selectively choosing a partner and applying good parenting.

On the intellectual aspect, Friends become determinants of the subject or not in scientific studies. Ensuring halal haram has not become a serious concern for most subjects. Urban teenagers from generation $\mathrm{Z}$ in this study have the potential to have a good future. Between one aspect and another aspect are interrelated. subjects who carry out all aspects well show their ability to solve problematic situations including parental divorce and control destructive attitudes and harm to the problems faced. In this case, religion is able to provide resources to explain and resolve problematic situations, increase feelings of power and ability (efficacy) in a person, and become the basis of feelings of meaning, direction, and personal identity, and potentially instill meaningful foreign events (Pollner, 1989). Ellison's research also shows that individuals who have strong religious beliefs reported higher life satisfaction, higher personal happiness, and experienced lower negative impact of traumatic events than individuals who did not have strong religious beliefs. The results of research by Freidman and his colleagues (in Taylor, 1995) also reported that religiosity greatly helped them when they had to overcome unpleasant events.

Overall psychological well-being of each adolescent from generation $\mathrm{Z}$ from divorced parents is good. In the autonomy dimension, most subjects have the ability to self-determination, are free, and have the ability to regulate their own behavior with their personal standards. While one subject tends to choose to surrender to the opposition of others even though his opinion is correct. This shows that subjects have low levels in this aspect because they are conformists to social pressure. In the dimension of environmental mastery, Regarding the dimensions of environmental control, through organization and leadership, all subjects hold, proving they are able to manage the environment to suit their psychological conditions in order to develop themselves.

In the personal growth dimension, four subjects have feelings about sustainable growth in themselves. This is also evidenced by responsiveness to new experiences and always increasing knowledge. Even some of the subjects have a lot of talent and abilities. The subjects also looked at the test of positive parental divorce by taking life lessons. While on the dimension of positive relationships with others, all subjects are able to establish relationships well. This shows that they compromise in maintaining relationships with others. Aspects of positive relationships with others are interpreted as the ability to love seen as a major characteristic of mental health. A warm relationship with others is one of the criteria of maturity (Ryff, 1989; Ryff \& Keyes, 1995).

In the dimension of life goals, each subject has a clear purpose in life. This is evidenced by knowing exactly what steps to achieve it. However, most of their life goals are still limited to the small scope of their families. Only one subject has a broader purpose, which is beneficial for many people. On the dimension of self-acceptance. A subject claims to be sensitive and tempered when asked to assess his shortcomings. Research conducted in Jogjakarta (Dewi, Dewi, Utami \& Listiyanto, 2008) found that adolescents who live with single parents divorced also tend to have low psychological well-being and high aggressiveness in their daily lives (in Aminah, 2012). Finally, adolescents from generation $Z$ have good religiosity and psychological well-being with their advantages and disadvantages in each aspect. This shows that generation $\mathrm{Z}$ of urban communities of divorced parents is able to make their lives meaningful by being proven through good religiosity and optimal mental health. 


\section{ACKNOWLEDGEMENT}

This research based on grant scheme of PITTA (Publikasi International Terindeks untuk Tugas Akhir) or also known as Indexed International Publications for Final Projects toward Universitas Indonesia students. Thank you to Nurwahidin and Thobib Al-Asyhar as my advisor.

\section{REFERENCES}

[1]. Aminah. (2012). Proses Penerimaan Anak (Remaja Akhir) Terhadap Perceraian Orangtua Dan Konsekuensi Psikosial Yang Menyertainya. Jurnal Imiah Psikologi Candrajiwa Volume 1, No. 3

[2]. Argyle, M. 2001. The Psychology Of Happiness. 2nd Edition. Sussex :Routledge

[3]. Dewi \& Utami. (2006). Subjective Wellbeing Anak Dari Orangtua Yang Bercerai. Jurnal Psikologi Volume 35, No.2, 194-212.

[4]. Elizabeth T. Santosa. (2015). Raising Children In Digital Era. Jakarta: Elex Media Komputindo.

[5]. Glock, C. Y., \& Stark, R. (1970). Religion And Society In Tension. San Francisco: Rand Mcnally.

[6]. Hellen Chou Pratama. (2012). Cyber Smart Parenting. Bandung: PT. Visi Anugerah Indonesia

[7]. Howitt, D Dan Cramer, D. (2011). Introduction To Research Methods In Psychology Third Edition. London : Pearson

[8]. Hurlock, E. B. (1980). Psikologi perkembangan: suatu pendekatan sepanjang rentang kehidupan. Jakarta: Erlangga.

[9]. Lexy J Moleong, (2002). Metodologi penelitian kualitatif, Bandung: PT. Remaja Rosda Karya.

[10]. Lopez, S. J. (2009). The encyclopedia of positive psychology. UK: Blackwell

[11]. Mangunwijaya, Y. B. (1986). Menumbuhkan sikap religiusitas anak. Jakarta: Gramedia

[12]. Najati, U. 2005. Al'Quran Dan Ilmu Jiwa. Jakarta : Aras Pustaka.

[13]. Pargament, K. I. 1997. The psychology of religion and coping. Ney York:

[14]. Publishing.

[15]. Ryan MR \& Deci E. 2001. On Happiness And Human Potentials: A Review Of Research On Hedonic And Eudaimonic Well-Being. Annual Rev. Psychol. 52: 141-166

[16]. Ryan RM, Deci EL. On Happiness And Human Potentials. A Review Of Research On Hedonic And Eudaimonic Well-Being.Annu Rev Psychol. 2001;52:141-66.

[17]. Ryff CD. (1989). Happiness Is Everything

[18]. Ryff, C.D \& Coorey L.M. Keyes.1995. The Structure Of Psychological Well -Being Revisited. Journal Of Personality And Social Pyschology.69. (719 -727).

[19]. Ryff, C.D. 1989. Happiness Is Everything Or Is It? Explorations On The Meaning Of Psychological Well - Being. Journal Of Personality And Social Pyschology.57.(1069 1081).

[20]. Ryff, D.C., \& Keyes, M.L.C. (1995). The Structure Of Psychological Well-Being Revisited. Journal Of Personality And Social Psychology, 69, 719-727.

[21]. Santrock, J. W. 2002. Life span development: perkembangan masa hidup Edisi 5 Jilid I. Jakarta: Erlangga.

[22]. Sarwono, S. W. 2001. Psikologi remaja. Jakarta: Raja Grafindo Persada.

[23]. Seifert, K.L. \& Hoffnung, R.J. 1987. Child and adolescent development. Boston: Houghton Mifflin Co. 
[24]. Singh, Anjali. International Journal Of Real Estate Studies, Journal Of Business And Management (IOSR-JBM) Volume 16, Issue 7. Ver. I. 2014, PP 59-63. Challenges And Issues Of Generation Z. Clinical Practice. New York: The Guilford Press

[25]. Strauss, A. \& Corbin, J. (1990), "Basics Of Qualitative Research: Grounded Theory Procedures And

[26]. Techniques," Newbury Park London New Delhi, Sage Publications.

[27]. Thouless, R.H. (2000). Pengantar Psikologi Agama. Penerjemah: Machnun Husein. Jakarta: PT Raja Grafindo Persada.

[28]. Yongmin Sun. (Aug., 2001), Journal Of Marriage And Family Vol. 63, No. 3 Pp. 697713

[29]. Yusuf, S. 2004. Mental hygiene: perkembangan kesehatan mental dalam kajian psikologi dan agama. Bandung: Bani Quraisy

[30]. Yusuf, S. 2005. Psikologi perkembangan anak dan remaja. Bandung: Rosdakarya. 